\title{
Geologiens Dage \\ - tema GeoSites
}

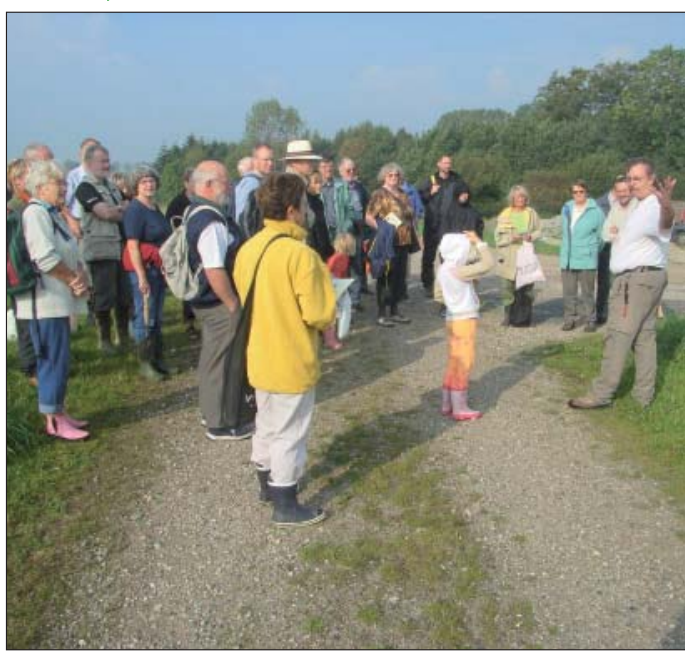

Ca. 40 besøgende mødte op i kalkgravene ved Klintholm til en god dag, hvor også TV2/Fyn var med. De bragte et indslag i de regionale nyheder om aftenen. (foto: Gert Laursen)

\section{Af geolog Ulla V. Hjuler, GeologiskNyt}

Geologiens dage blev i år afholdt lørdag d. 30. september og søndag d. 1. oktober. Over 50 arrangementer gav alle geologiinteresserede rig mulighed for at vælge mellem spændende ture over hele landet.

Det var Nationalkomiteen for Geologi, der stod bag arrangementet, og temaet for

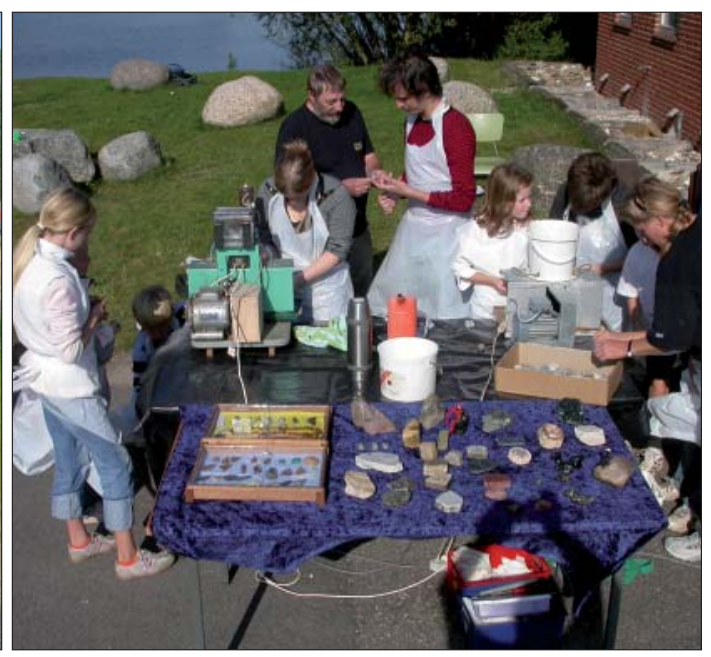

Over 2 dage var der et par hyggelige ture til hhv. Vissenbjerg Bakker og Tarup-Davinde. Billedet hér stammer fra stenslibningen for børn søndag eftermiddag i strålende sol. (Foto: Bent Nielsen)

Geologiens Dage var GeoSites - det er lokaliteter, der nationalt og internationalt har en særlig betydning for udredningen af Jordens geologiske historie, og netop i efteråret 2006 skulle Danmark udpege de danske GeoSites kandidater. 30 af årets arrangementer var relateret til temaet.

Desuden var der åbenthus-arrangementer med mulighed for at se specialudstillinger, besøge stenslibere, få bestemt sine fund $\mathrm{og}$ for de friske var der planlagt en ekskusion til Skelhøje med cyklen som transportmiddel.

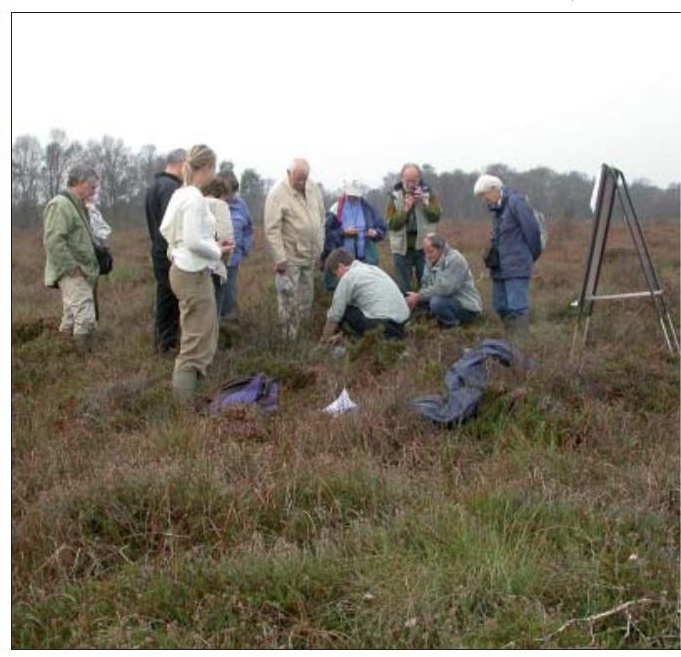

En borekerne foretaget gennem et moselag studeres ncermere. Lokaliteten er Lille Vildmose, hvor professor Bent Odgaard bl.a. fortceller om mosens udvikling. (Foto: En interesseret deltager)
Mange udflugtsmål inde som ude Vejret var blandet, men overvejende fint, så for dem, der havde valgt en ekskursion, var der rig lejlighed til at nyde geologien "in situ”. Bl.a. besøgte omkring 150 mennesker den bornholmske Sorte Gryde, der i dagens anledning var oplyst af fakler. Mere end 80 deltagere nød en tur i Fakse Kalkbrud, mens omtrent 115 entusiaster kiggede på bl.a. klimper og indlandsklitter i Frøslev Plantage. Håbet er at gennemføre Geologiens Dage igen i 2008. 